\title{
REFLECTING UPON FAKE NEWS IN TODAY'S POST-TRUTH ERA
}

PROBLEMS

OF EDUCATION

IN THE $21^{\text {st }}$ CENTURY

Vol. 79, No. 4, 2021

513

\author{
Solange W. Locatelli \\ Federal University of $A B C$, Brazil \\ E-mail: solange.locatelli@ufabc.edu.br
}

We are living in an era, in which people are constantly asking themselves: how can anyone believe this news that is clearly false? Reflecting on this, a brief reflection on some factors that can influence people to take this kind of news into account is brought here, as well as presenting an example of Fake Science that circulated on social networks in 2020 in Brazil, during the pandemic context.

First, it can be considered that a significant objective in Science Education is making students scientifically literate, prepared for appropriate decision-making. Chassot (2003, p. 19) considers scientific literacy as "the set of knowledge that would make it easier for men and women to read the world in which they live". Leung (2020) adds that, nowadays, it is very important to recognize the veracity of information, differentiating it from fake news, which also encompasses the concept of scientific literacy, which brings us to the statement by Gomes et al. (2020) on media literacy, so that citizens can connect more to facts and less to emotions in understanding the news.

In this way, it is intended that people can have a critical and reflective view of the world (including the digital), with a more appropriate view of what reaches them through the media, social networks, etc. in a movement to question the facts or the emotions aroused by biased news, with the autonomy to be able to check the facts properly. This is a substantial objective in Science Education, among others.

Médran (2017) has criticized the creation of alternative realities in which the central point, precisely, are emotions, as opposed to concrete facts (post-truth era) and states that this is not something new, the difference being the speed with that this happens nowadays, since, at the same time as the problem is quickly identified, the fake news is also propagated with high speed.

In this sense, it is up to us, increasingly, to bring the truth to light, using the necessary, possible and viable means to strengthen democracy, since the internet is there and it seems to us a path with no return, and according to Chang and Borin (2021), fake news aims to modify or even change public opinion on some topic of interest. This fact highlights the importance of identifying and combating it.

As an example, the pandemic context is cited, which has already killed more than half a million people (so far) in Brazil and, even so, some people have refused using face masks and have preferred taking medicines without any efficacy against COVID- 19, based on fake news that are disseminated daily, or even in alternative realities as mentioned by Médran (2017), with the emotional nature prevailing over reason. Hopf et al. (2019) referring to the post-truth era, explain that fake news can reduce people's belief in science, even in life-or-death matters, which is the case in question here.

For this, in an attempt to bring the truth to its place, so that people are not manipulated using false information, relying on their beliefs and their emotions, it is essential to understand why people believe in fake news. This reinforces how relevant it is to deal with this topic, identifying some elements that make this fake news so "reliable". 
PROBLEMS

OF EDUCATION IN THE $21^{\text {st }}$ CENTURY Vol. 79 , No. 4,2021

514

Gomes et al. (2020) carried out a research with 232 subjects through a questionnaire to investigate what would be the elements that influence people to believe in scientific fake news. The results indicated that some factors may be associated, such as family income and education level, which makes these people more susceptible to believe in fake news. Furthermore, some researchers such as Gomes et al. (2020) consider the use of classical Aristotelian rhetoric, which is made up of 3 elements, whose objective is to facilitate credibility in fake news: logos, associated with reason, with reasoning; pathos, which would be the way emotions are aroused in the reader, and ethos, something that brings credibility to ideas, authority.

An example that is brought here to illustrate, was fake news, that circulated on social networks in Brazil in 2020, saying that a "virology magazine" (ethos) published that "all we need to do, to defeat the coronavirus..." (pathos), would be to eat foods that were of a basic character since the virus causing COVID-19 would be acid (logos), as an example of acid foods, the message cited "lemon ( $\mathrm{pH}=9.9)$, avocado $(\mathrm{pH}=15.6)$ ", etc., present at home.

In this example, we identify the Aristotelian persuasive logic in the fake news, containing the 3 elements of the Aristotelian persuasion, which may have helped to give credibility to the news that, unfortunately, was widely disseminated by social media in 2020 in Brazil. The fact that it was supposedly published in a "virology magazine" confers the character of authority (ethos). With regard to logos, the concepts of chemistry (for example) were used mistakenly, such as the concept of $\mathrm{pH}$, acidity and alkalinity associated incorrectly, the $\mathrm{pH}$ of the lemon being wrongly high, indicating that it would be basic and also the avocado $\mathrm{pH}$ being a value above 14. However, the way the news was presented, for someone who is unaware of scientific concepts, it could be seen as something logical, argumentative (using: since...then). And finally, the emotional appeal (pathos), because everyone in the world wants to hear that we already have a cure or a medicine that fights the virus and still invites everyone to "beat" the virus. This news, loaded with false information, refers to Chang and Borin (2021) when they state that this type of news "ends up promoting a scientific culture in reverse, as science and technology are presented in a wrong way, both with regard to its content, as to the perceptions of science, as is the case of a simple science for the solution of complex problems" (p. 140).

This is just to identify some aspects and bring the reader some reflections. In this reflection exposed here, the importance of the individual being scientifically literate is highlighted (having a vision of and about science, as well as basic concepts of chemistry and biology, for example) and also mediatically (having the autonomy to seek and identify fake news with focus on reason and not emotion), which, in turn, has strong implications in the science classroom, in which the teacher could assess this news with students, identifying misconceptions and conceptual errors, so that students could develop the metacognitive skills necessary to have autonomy in learning to learn.

\section{References}

Cunha, M. B., \& Chang, V. R. J. (2021). Fake Science: uma análise de vídeos divulgados sobre a pandemia [Fake science: An analysis of published videos about the pandemic]. Amazônia: Revista de Educação em Ciências e Matemática, 17(38), 139-152. http://dx.doi.org/10.18542/amazrecm.v17i38.10166

Chassot, A (2003). Alfabetização científica: uma possibilidade para a inclusão social [Scientific literacy: A possibility for social inclusion]. Revista Brasileira de educação, 21, 157-158. https://doi.org/10.1590/S1413-24782003000100009

Gomes, S. F., Penna, J. C. B. O., \& Arroio, A (2020). Fake news científicas: Percepção, persuasão e letramento [Scientific fake news: Perception, persuasion and literacy]. Ciência \& Educação, 6, e20018. https://doi.org/10.1590/1516-731320200018

Hopf, H., Krief, A., Mehta, G., \& Matlin, S. A (2019). Fake science and the knowledge crisis: Ignorance can be fatal. Royal Society Open Science, 6(5), 1-27. https://doi.org/10.1098/rsos.190161 
Leung, J. S. C. (2020). A practice-based approach to learning nature of science through socioscientific issues. Research in Science Education, 1-27. https://doi.org/10.1007/s11165-020-09942-w

Medrán, A. (2017). In the kingdom of post-truth, irrelevance is the punishment. UNO, São Paulo, 27, 33-35. https://www.uno-magazine.com/number-27/kingdom-post-truth-irrelevance-punishment/

Received: July 15, 2021

Accepted: August 04, 2021 